УДК 930.26

\title{
Dwarfs in Ancient Armenia
}

\author{
Anahit Yu. Khudaverdyan* \\ Institute of Archaeology and Ethnography \\ National Academy of Science, Republic of Armenia \\ 15 Charents Str., Yerevan, 0025, Armenia
}

Received 16.05.2015, received in revised form 15.06.2015, accepted 11.09.2015

In modern publications dwarfism is uncommon. Here I report a case of possible pituitary dwarfism encountered in a routine analysis of the Beniamin site from the Armenia (Classical/Late Antiquity period). I have also interpreted some of the information with the goal of presenting some information about the life histories of individual.

Keywords: Armenia, Late Antiquity period, dwarfism, osteoarthritis, non-specific lesions.

DOI: 10.17516/1997-1370-2015-8-11-2201-2211.

Research area: history.

\section{Introduction}

The paleopathological literature on dwarfism and other skeletal dysplasias points to the multitude of factors that can cause an individual to be reduced in size (Waldron 2009, Ortner 2003). Waldron suggests that the best way to confirm pituitary dwarfism would be to demonstrate that it is drastically smaller than other individuals in the population, but that it is still in proportion (Waldron 2009, p. 195). Roberts (1987), using a similar approach, describes a potential case of pituitary dwarfism in a Roman population. The criteria she used for diagnosing the case focused on the proportions of the long bones and the lack of complete epiphyseal union (Roberts 1987, p. 1659). Ortner (2003) describes the ways in which pituitary dwarfism specifically can present in the skeleton. Hypopituitarism, a condition that has been attributed to TC 300R (Terry collection records 300R), affects the skeletal system only in the case of a pituitary disturbance during childhood (Ortner 2003, p. 422). This condition is described as a "reduced growth in length and width of the bones" (Ortner 2003, p. 422). There have been several other publications that looked at cases of dwarfism in various populations (Dasen 1988, Ortner, Hotz 2005, p. 5; Hernandez 2011, p. 2-3; Slon et al. 2011, p. 14-15). These papers explore various forms, including hypopituitarism (Hernandez 2011, p. 11), hypothyroidism (Ortner, Hotz 2005, p. 6) and achondroplasia (Slon et al. 2011, p. 15).

According to Roberts, Manchester (2005, p. 2) "the curiosity factor in dwarfism" has "led to abundant representations of these conditions in art" in different cultures and chronologies. The representation of dwarf individuals in iconography has been common since ancient

(C) Siberian Federal University. All rights reserved

* Corresponding author E-mail address: akhudaverdyan@mail.ru 
times (Kozma 2006, p. 307). In different cultures dwarfs have been objects of curiosity and/or veneration (Haworth, Chudley 2001, p. 85; Waldron 2009). The first depiction reported belongs to an 'indigenous male dwarf' (índio anão), called Marcelino, from the Tanarana ethnic group (Ferreira 1971). The watercolors show an individual presenting a short stature with normally proportioned head, shortened upper and lower limbs. The thumbs and hallux look divergent from the other fingers and toes. Considering the differential diagnosis of Marcelino's dwarfism, the Turner's syndrome, that consist in a total or partial lack of one of the $\mathrm{X}$ chromosomes, is easily excluded since it only occurs in women and it is an extremely rare event (Waldron 2009, p. 197).

Causes of pituitary dysfunction in childhood may have a neoplasm origin (Aufderheide, Rodríguez-Martín 1998; Ortner 2003, p. 424) or, but far less common, a traumatic or congenital deformity or enzyme deficiencies, among others etiologies (Aufderheide Rodríguez-Martín 1998). According to these authors, other characteristics described for this condition are the lack of appropriate development of the external genitals and the premature epiphyseal closure, both resulting from the decrease of gonadotropin production. Another possible diagnosis is achondroplasia, a congenital and hereditary disease, also denominated short-limbed dwarfism. It is the most common form of non-lethal skeletal dysplasia (Ortner 2003; Waldron 2009). In these cases intelligence is normal (Ortner 2003, p. 422). Achondroplastic individuals appears to have disproportionately large head, "which is only partly an illusion due to its brachycephalic shape with frontal bossing and a shortened cranial base that leads to a depressed nasal bridge" (Aufderheide, Rodríguez-Martín, 1998, p. 358).

In this paper, I will demonstrate that both individual are significantly shorter than other individuals in the Beniamin site. Independently of the limitations concerning the acknowledgment of the exact nosological entity responsible for the body changes presented by Beniamin site, his depiction is very relevant since it shows that dwarfism was present in individual in Classical/ Late Antiquity period in Armenia.

The anthropological material presented in this work was collected with the assistance of the author. Morphological analysis of the material has revealed the heterogeneity in the population of the Beniamin site (Khudaverdyan 2012a, p. 1115). Intragroup analysis has revealed two groups within this population. The horizontal profile of the face in one of these groups (group II) is slightly attenuated. It is necessary to state that carriers of two groups remind one of Scythians from the territory of Moldova, Steppes of Black Sea Coast, Ukraine, Sarmatians from the Volga region and Saka from the territory of Turkmenistan (Khudaverdyan 2012a: 30-31). These conclusions are consistent with those reported by other biodistance studies that examined nonmetric cranial and dental for Beniamin sample (Movsesyan, Kochar 2001, p. 99; Khudaverdyan 2012b, p. 140, 2014a, p. 49). This scenario is consistent with other archaeological and historical studies of the area which show the long-standing presence of Scythians in the Caucasus (Strabo IV; Piotrovsky 1959, p. 128; Eremyan 1968, p. 91).

\section{Materials and Methods}

Between 1989 and 2006 the Institute of Archaeology and Ethnography, National Academy of Science, Republic of Armenia and the Shirak Museum conducted a joint excavation at Beniamin. The Beniamin collection, one of the few large collections in the Armenia (Fig. 1).

Data from excavations suggest that a small farming community occupied the site from at least 1 st century $\mathrm{BC}-3 \mathrm{rd}$ century AD. A total of 350 burials were recovered from Beniamin 


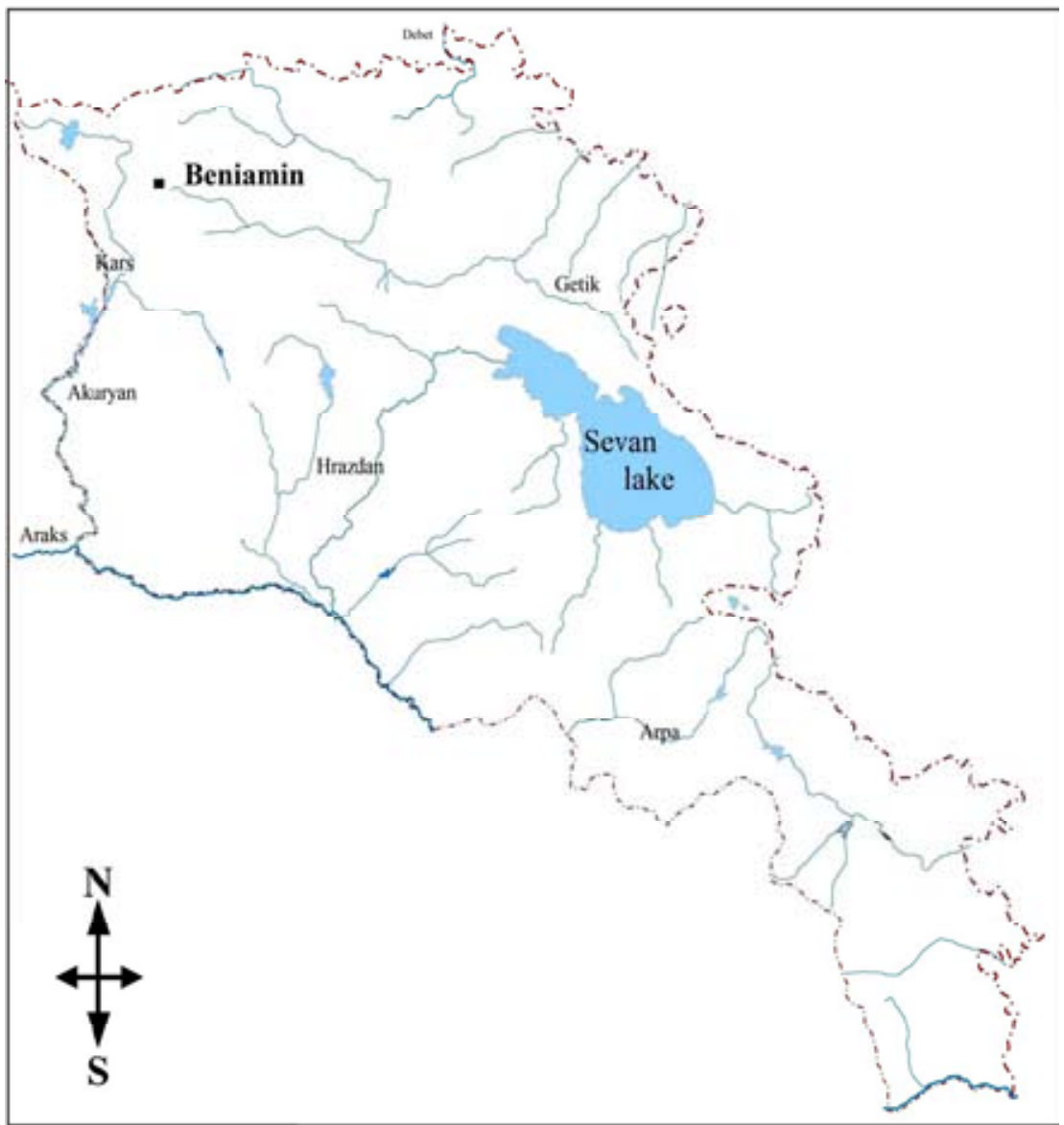

Fig. 1. Map of Armenia showing the location of the site

during field seasons from 1989 to 2006. Grave associations were generally uncommon, and when present, usually consisted of small personal items like tupu pins, goods including metalwork, pottery, etc. Individuals were placed in extended positions. The sample consisted of 165 individuals: 63 from females, 44 from males, 57 from subadults. One adult individual was of undetermined sex (very fragmented skull, absent pelvic bones). Although I have published reports of our work (Khudaverdyan 2010, p. 20-38, 2014 b, p. 229), but the pituitary dwarfism of the skeletal remains from Beniamin site has not been published.

Age-at-death and sex of adult was assessed through the use of morphological features of the pelvis were used for the determination of sex (Phenice 1969, p. 298-230; Buikstra, Ubelaker 1994, p. 16); a combination of pubic symphysis (Gilbert, McKern 1973, p. 34; Katz, Suchey 1986, p. 431; Meindl et al. 1985, p. 59), degree of epiphyseal union (Buikstra, Ubelaker 1994: 16), were used for adult age estimation. Long bone length is measured according to Alekseev (1966).

\section{Discussion}

Examination of the burials from a Antique cemetery site in Beniamin showed a skeleton (burial 221) of small proportions (Figs. 2-5). Pelvic morphology suggests that the remains are those of a woman, aged 40-45 years. The skull 


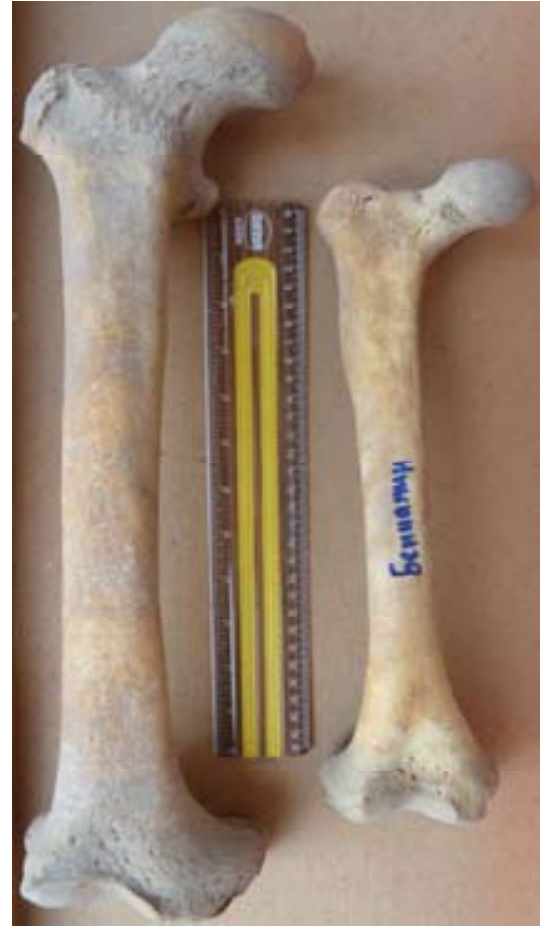

Fig. 2. Pituitary dwarf: Compartive anterior views of a right normal and abnormal femur

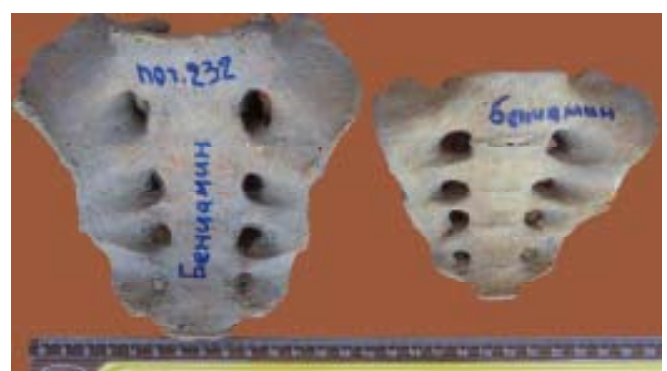

Fig. 4. Pituitary dwarf: Compartive anterior views of a normal and abnormal sacrum

was missing. The bones are all gracile, slender, and shorter than normal but in proportion with each other. The major diagnostic criteria applied are listed in Table 1

Comparison with a dataset of an population from Beniamin with dwarf-female from burial 221 shows that she was significantly shorter than the mean of the female population of this period. The femoral length is about 357 millimeters or

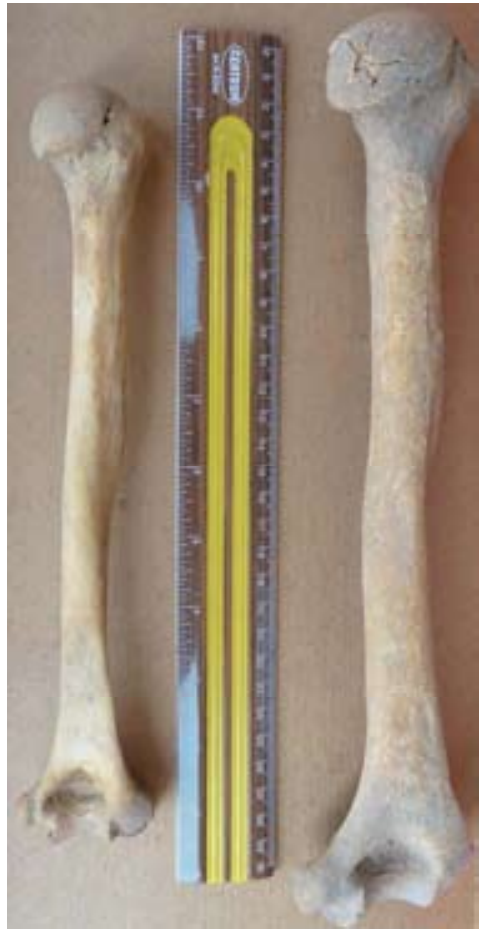

Fig. 3. Pituitary dwarf: Compartive anterior views of a right normal and abnormal humerus

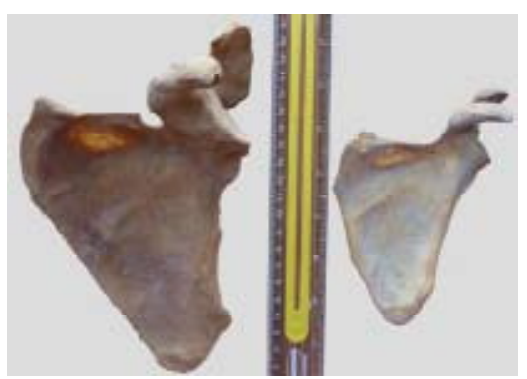

Fig. 5. Pituitary dwarf: Compartive anterior views of a normal and abnormal scapula

75 percent of the expected length. Dwarf-female is a fairly symmetrical individual in terms of maximum lengths of long bones. The greatest difference in length is on the maximum length of the tibia, where the left tibia is $8 \mathrm{~mm}$ longer than the right. Otherwise, differences in lengths range from 2 to $4 \mathrm{~mm}$. In all cases the left element has a greater maximum length than the right. 
Table 1. Osteological characteristics

\begin{tabular}{|c|c|c|c|c|}
\hline Element & Measurement & \multicolumn{2}{|c|}{ Pituitary Dwarfism } & $\begin{array}{c}\text { Beniamin } \\
\text { (female site) }\end{array}$ \\
\hline \multirow[t]{3}{*}{ Scapula } & Height & $175 ?$ /right/ & $180 /$ left/ & - \\
\hline & Width & 89 /right/ & $90 /$ left $/$ & - \\
\hline & Scapular index & 50.86 & 50 & - \\
\hline \multirow{5}{*}{ Humerus } & Length & 262 /right/ & 265 /left/ & $297.8(17)$ \\
\hline & Head vertical diameter & 28 /right/ & 28.2 /left/ & - \\
\hline & Shaft maximum diameter & 18.5/right/ & $18.8 / \mathrm{left} /$ & $20.3(17)$ \\
\hline & Shaft minimum diameter & 13 /right/ & 13 /left/ & $15.4(17)$ \\
\hline & Epicondylar width & 39 /right/ & 39 /left/ & $47.1(20)$ \\
\hline \multirow{5}{*}{ Radius } & Length & 197 /right/ & $200 /$ left/ & $226.9(17)$ \\
\hline & Physiological length & 183.8 /right/ & 184.5/left/ & $214,2(20)$ \\
\hline & Transverse diameter & 12/right/ & $12.5 /$ left $/$ & $14.1(17)$ \\
\hline & Antero-posterior diameter & 8 /right/ & 10 /left/ & $10.2(17)$ \\
\hline & Shaft minimum diameter & 30 /right/ & 32 /left/ & $36.9(20)$ \\
\hline \multirow{4}{*}{ Ulna } & Antero-posterior diameter & 12.5/right/ & - & $11,31(20)$ \\
\hline & Transverse diameter & 9 /right/ & - & $14.95(20)$ \\
\hline & Maximum length & 212 /right/ & - & $246.07(16)$ \\
\hline & Physiological length & 189/right/ & - & $243.8(15)$ \\
\hline \multirow[t]{2}{*}{ Sacrum } & Length & \multirow{2}{*}{\multicolumn{2}{|c|}{$\begin{array}{c}89 \\
104\end{array}$}} & - \\
\hline & Breadth & & & - \\
\hline \multirow[t]{4}{*}{ Femur } & Maximum length & 356/right/ & 358/left/ & $415.8(10)$ \\
\hline & Mid shaft circumference & 65 /right/ & 68 /left/ & $77.1(18)$ \\
\hline & Med-lat mid-shaft diameter & 21/right/ & 22/left/ & $25.7(17)$ \\
\hline & Ant-post mid-shaft diameter & 20.3/right/ & 21/left/ & $23.7(17)$ \\
\hline \multirow[t]{5}{*}{ Tibia } & Total length & 289 /right/ & 296/left/ & 338.7 (17) \\
\hline & Maximum length & 292 /right/ & 300 /right/ & $346(16)$ \\
\hline & Med-lat diameter at foramen & 16/right/ & 17.5 /left/ & $21.5(20)$ \\
\hline & Ant-post diameter at foramen & 24/right/ & 25 /left/ & $30.1(20)$ \\
\hline & Shaft minimum diameter & 63.5 /right/ & 65 /left/ & $67.9(20)$ \\
\hline \multirow[t]{2}{*}{ Fibula } & Length & 279 /right/ & $283 /$ left/ & $329.47(13)$ \\
\hline & Maximum height & 149.8/right/ & $155.5 /$ left/ & $196.1(10)$ \\
\hline \multirow[t]{2}{*}{ Hip joint } & Iliac width & 102/right/ & $102.5 / \mathrm{left} /$ & $149.1(11)$ \\
\hline & Ilium height & 125/right/ & $125 / \mathrm{left} /$ & - \\
\hline
\end{tabular}

The left scapula measures $5 \mathrm{~mm}$ higher than the right. Less significant differences in measurements include humeral maximum length (the left side is $3 \mathrm{~mm}$ longer than the right), maximum length of the radius (the left side is $3 \mathrm{~mm}$ longer than the right). The smallest differences in measurement values are in the femora. The left femur is $2 \mathrm{~mm}$ longer than the right (maximum length).

The femur/tibia maximum length ratio illustrates the disproportionately short length of the femur $(85.76 / \mathrm{left} /)$, that she was significantly smaller, than the mean of the female population of this period. The mean index value for all other 
individuals from Beniamin was 121. This ratio further illustrates the disproportionately short lengths of the femora. The ratio of humerus maximum length to radius maximum length was calculated to see, whether there was a distinction in the proportions of the upper arm to lower arm. This index value was $77.56 /$ right/ and 77.83 / left/. This ratio shows that the arm bones for dwarffemale are fairly close proportionately to the individuals of normal stature.

The humero-femoral index are significantly higher (78.45) than the mean index value for all non-dwarfed individuals (73.5). The humerofemoral index of dwarf-female shows that, at least in terms of the humerus and the femur, the individual shows normal proportions. This shows that female is not proportional, and therefore a less 'classic' case of pituitary dwarfism, or is perhaps not a pituitary dwarf at all.

It is difficult to calculate stature for dwarfed individual, since Alekseev (1966) does not provide stature estimates for individuals with femora as short as those of female from Beniamin.

The vertebrae are small but of normal proportions. The sacrum and innominates are small but of fairly normal proportions.

Paleopathological analysis is one of the various analytical tools frequently used by physical anthropologists in bioarchaeology. Diseases which are of special interest to osteologists are those which are activity-related pathological conditions such as osteoarthritis (Jurmain, Kilgore 1995, p. 448; Jurmain 1999, p. 17). Osteoarthritis is a degenerative disease of the appendicular joints which affects both the cartilage and underlying bone. Osteoarthritis can manifest one of two forms, primary and secondary. Primary osteoarthritis is idiopathic or unknown in nature, and secondary osteoarthritis is the result of a previous injury to the joint (Ortner 2003; Rogers, Waldron 1995, p. 79). Primary osteoarthritis will generally develop bilaterally whereas secondary will manifest unilaterally.

The formation of new bone (osteophytes) can be observed around the margins of the acetabulum (Fig 6), which is also referred to as (slight) lipping. Marginal osteophytes on the acetabulum can be quite variable in severity. This characteristic is often described in regards to extent of joint surface covered, and the degree for which it is raised (Buikstra, Ubelaker 1994). The acetabulum female (Fig. 6) exhibits multiple characteristics of osteoarthritis such as eburnation, osteophytic marginal lipping, and porosity.

The next feature observed is porosity of the diaphyseal ends, particularly noticeable on the femoral neck bilaterally (Fig. 7). The reactive areas on the femora called anterior cervical imprints, or Allen's fossae (Capasso et al. 1999, p. 37).

This facet is found on the anterior aspect of the medical femoral neck and is due to hyperextension of the femur and rotation of the head in the acetabulum, usually from downhill walking or traversing mountainous landscapes.

The degeneration of the insertion area of the infraspinate and teres minor muscles (rotator cuff) on the humeral bones (Fig. 8), suggesting an pathological stress episode rather than a habitual effort on the shoulder. Rugosity is apparent when the bone surrounding the facet thickens around attachment sites, mechanical loading induces bone remodeling. The type and the magnitude of the response can vary depending on several factors (e.g. genetic predisposition, health, etc.). Robusticity markers are always observable, although with variable degrees of expression, while enthesopathies can be absent or present (Hawkey, Merbs 1995, p. 328; Mariotti et al. 2004, p. 146, 2007, p. 293; Ruff et al. 2006, p. 496). The upper body, including the humeri, radii and ulnae exhibit hypertrophied muscle and 


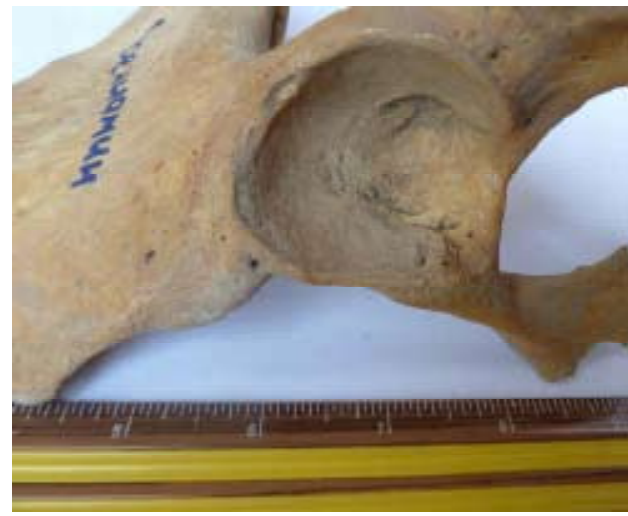

Fig. 6. Eburnation, osteophytic marginal lipping, and porosity

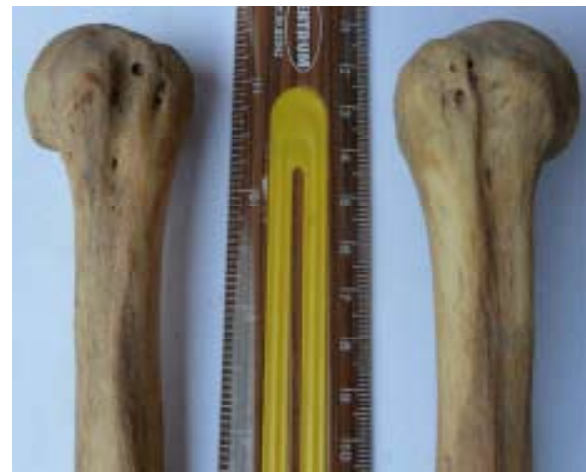

Fig. 8. Right and left humerus, anterior view, proximal head, showing various size "pits"

ligament attachments that result from repetitive heavy labor using the muscles of the upper body including the upper back, chest muscles and arm muscles (Figs. 8-10).

This individual had evidence of osteoarthritis and mechanical stress in the lumbar, thoracic vertebrae as indicated by the presence of Schmorl $\square$ s nodes (Fig. 11). Although the specific cause of Schmorl's nodes is unknown, it is likely that they are caused by carrying heavy loads on the back (Coughlan, Holst 2000, p. 67), linked to development, congenital spinal defects and senescence (Wu et al. 2006, p. 215; Faccia, Williams 2008, p. 31) and linked to activities such as horse-riding (Jurmain 1999, p. 22). Can

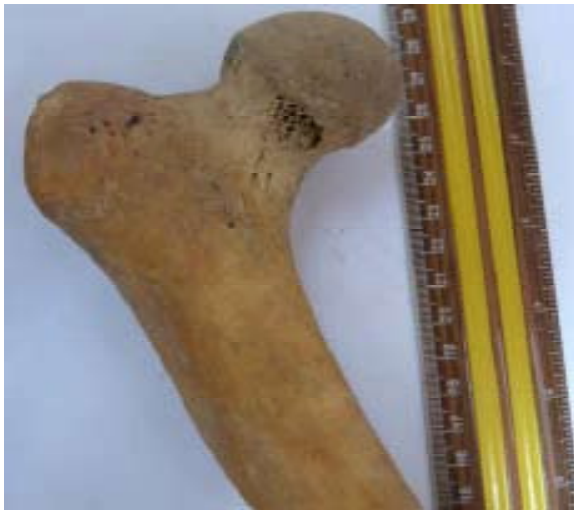

Fig. 7. Allen's fossa located inferior to the anterior articular surface of the femoral head

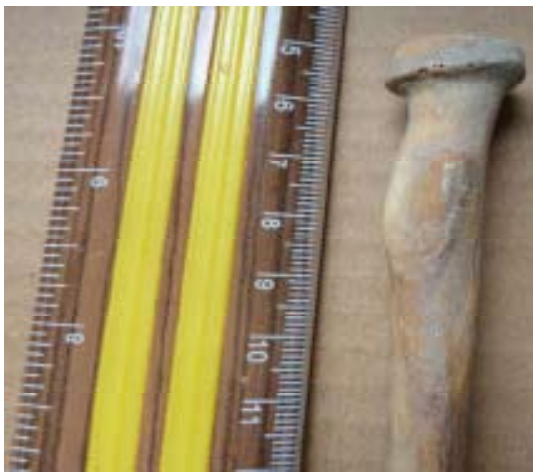

Fig. 9. Hypertrophic on the radii, the cortical bone looks thick and compact

be often observed on the flat parts of the bodies and intervertebral facets (Fig. 11).

The female also exhibited reactive woven and sclerotic inflammatory bone responses to infection, also termed periostitis. Non-specific lesions indicate a chronic inflammation of the periosteum (Fig. 12) that affected predominantly on the tibiae. The adult had active infection at the time of death in the tibia. Reactive woven bone displays sharp edges and is indicative of active infection at the time of death.

The individual has a minor congenital defect of the sacrum. In more severe cases it is known as 'spina bifida', though in this case it is a cleft of the 1st sacral spine with a the incomplete anterior 


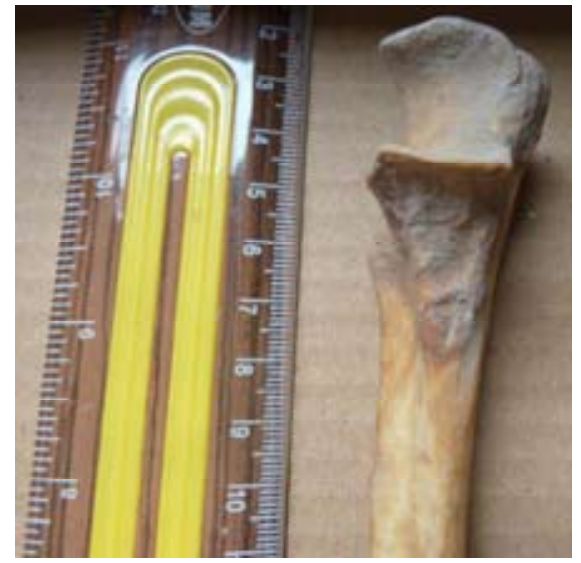

Fig. 10. Hypertrophic brachialis insertions on the ulna sacral vertebrae

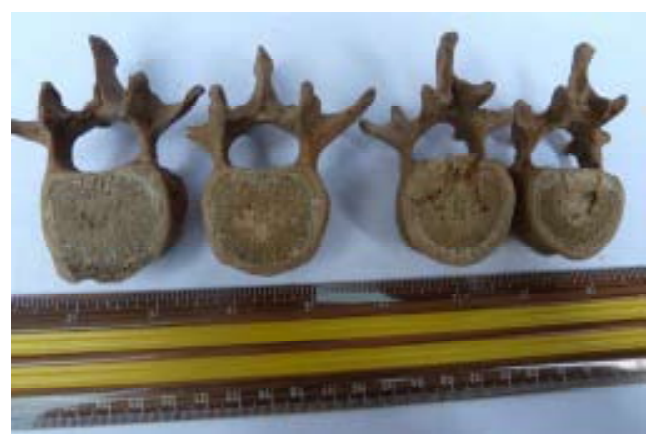

Fig. 11. Osteoarthritis in the spine with 'Schmorls nodes'

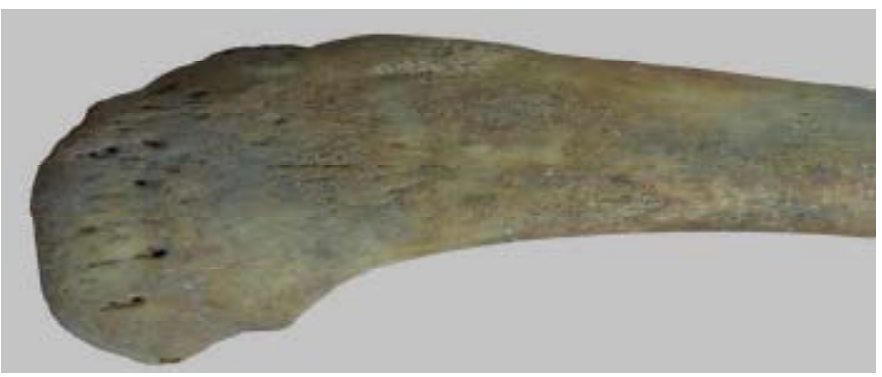

Fig. 12. Tibiae: non-specific lesions indicate a chronic inflammation of the periosteum
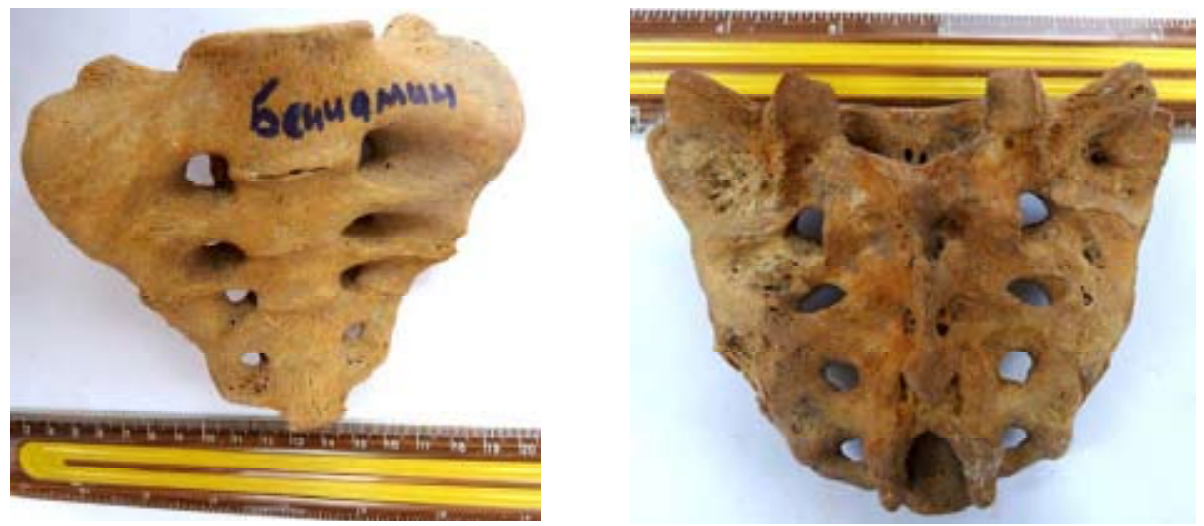

Fig. 13. A cleft of the 1st sacral spine. High density of nutrient foramina 
central lumbarization (separation) (Fig. 13). It is an inherited condition and would have had little to no effect on the individual's health.

\section{Conclusion}

The findings in this skeleton suggest proportionate dwarfism, which has several possible causes, among which pituitary dwarfism is the most likely. In keeping with portions of the osteobiographical approach, I have done exhaustive descriptions of the skeletal material. I have also interpreted some of the information with the goal of presenting some information about the life histories of individual. Individual exhibit arthritic changes, changes associated with age. Muscle attachment sites indicate that individual would have been engaged in more strenuous activity throughout life.

\section{References}

Alekseev V. P. Osteometriya (metodika anthropologicheskikh issledowanii) [Osteometry (methods of anthropological research)]. Moscow: Nauka, 1966, $251 \mathrm{p}$.

Aufderheide A. C., Rodriguez-Martin C. The Cambridge Encyclopedia of Human Paleopathology, Cambridge, Cambridge University Press, 1998, 496 p.

Buikstra J. E., Ubelaker D. H. (1994). Standards of data collection from human skeletal remains. Arkansas Archaeological Survey Research Series, 44. Fayetteville. 218 p.

Capasso L., Kennedy K. A. R., Wilczak C. A. (1999). Atlas of occupational markers on human remains. Journal of Paleontology Monographic Publication, (3).

Coughlan J., Holst M. (2000). Health status. Blood Red Roses: The Archaeology of a Mass Grave from the Battle of Towton AD 1461. Fiorato V., Boylston A, Knüsel C. (eds.). Oxbow Books, 2000, 60-76.

Dasen V. (1988). Dwarfism in Egypt and classical antiquity: iconography and medical history. Medical History, 32(3), 253-276.

Eremyan S. T. (1968). Invasions Cimmerian and Scythian tribes and fight Assyria and Urartu against nomads. Journal of History and Philology, 2 (41), 89-116.

Faccia K. J., Williams R. C. (2008). Schmorl's nodes: clinical significance and implications for the bioarcheological record. Int J. Osteoarchaeol, 18, 28-44.

Ferreira A. R. (1971) Viagem filosófica pelas capitanias do Grão Pará, Rio Negro, Mato Grosso e Cuiabá: 1783-1972: Iconografia. Rio de Janeiro, Conselho Federal da Cultura.

Gilbert B. M, McKern T. W. (1973). A method for aging the female os pubis. Am J Phys Anthropol, $38,31-38$.

Haworth J. C., Chudley A. E. (2001) Dwarfs in art. Clinical Genetics, 59(2), 84-87.

Hawkey D. E, Merbs C. F. (1995). Activity-induced musculoskeletal stress markers (MSM) and subsistence strategy changes among ancient Hudson Bay Eskimos. Journal of Osteoarchaeology, 5, 324-338.

Hernandez M. (2011). A Possible Case of Hypopituitarism in Neolithic China. Int J Osteoarchaeol, 23 (4), $432-446$.

Jurmain R.. Stories from the skeleton: Behavioral reconstruction in human osteology. Amsterdam, Gordon and Breach Publishers, 1999, 334 p.

Jurmain R., Kilgore L. (1995). Skeletal evidence of osteoarthritis: a paleopathological perspective. Annual Review of Rheumatic Disease, 54, 443-450. 
Katz D., Suchey J. M. (1986). Age determination of the male os pubis. Am J Phys Anthropol, 69, 427-435.

Khudaverdyan A.Yu. (2010). Pattern of disease in three 1st century BC - 3rd century AD burials from Beniamin, Vardbakh and the Black Fortress I, Shiraksky plateau (Armenia). Journal of Paleopathology, 22, 15-41.

Khudaverdyan A. Yu. (2012a). A bioarchaeological analysis of the population of the Armenian Highland and Transcaucasus in the Antiquity. The Mankind Quarterly, 53 (1), 3-35.

Khudaverdyan A. Yu. (2012b). Nonmetric cranial variation in human skeletal remains from Armenian Highland: microevolutionary relations and intergroup analysis. European Journal of Anatomy, 16 (2), 134-149.

Khudaverdyan A. Yu. (2014a). A dental non-metric analysis of the Classical/Late Antiquity period $\left(1^{\text {st }}\right.$ century $\mathrm{BC}-3^{\text {rd }}$ century AD) population from Armenian Plateau. Papers on Anthropology, XXIII/2, 47-66.

Khudaverdyan A. Yu. (2014b). Les inhumations de la cimetières de la plaine Chirak (Arménie), approche biologique et sociale. Etnoantropoloљki problem, 9 (1), 219-242.

Kozma C. (2006). Dwarfs in ancient Egypt. Am J Med Gen, 140A(4), 303-311.

Mariotti V., Facchini F., Bellcastro M. G. (2004). Enthesopathies - Proposal of a Standardized Scoring Method and Applications. Collegium Antropologicum, 28(1), 145-159.

Mariotti V., Facchini F., Belcastro M. G. (2007). The Study of Entheses: Proposal of a Standardised Scoring Method for Twenty-Three Entheses of the Postcranial Skeleton. Collegium Antropologicum, 31(1), 291-313.

Meindl R. S., Lovejoy C. O. (1985). Ectocranial Suture Closure: A Revised Method for the Determination of Skeletal Age at Death Based on the Lateral-Anterior Sutures. Am J Phys Anthropol, 68, 57-66.

Movsesyan A. A., Kochar N. R. (2001). Ancient populations of Armenia and their role in contemporary Armenian type formation. The Anthropology Bulletin, 7, 95-116.

Ortner D. J. Identification of Pathological Conditions in Human Skeletal Remains. USA Academic Press, 2003, 645p.

Ortner D., Hotz G. (2005). Skeletal Manifestations of Hypothyroidism from Switzerland. Am J Phys Anthropol, 127, 1-6.

Piotrovsky B. B. Vansky kingdom (Urartu). Moscow: East literature, 1959, 284 p.

Phenice T. W. (1969). A newly developed visual method of sexing the os pubis. Am J Phys Anthropol, 30, 297-302.

Rogers J., Waldron T. A Field Guide to Joint Disease in Archaeology. John Wiley, New York, 1995, $119 \mathrm{p}$.

Roberts C. (1987). Possible pituitary dwarfism from the Roman period. British Medical Journal, 295(6613), 1659

Ruff C., Holt B., Trinkause E. (2006). Who's afraid of the Big Bad Wolff?: "Wolff 's Law" and bone functional adaptation. Am J Phys Anthropol, 129, 494-498.

Slon V., Nagar Y., Kuperman T., Hershkovitz I. (2011) A Case of Dwarfism from the Byzantine City Rehovot-in-the-Negev, Israel. Int J Osteoarchaeol, 23 (5), 573-589. 
Strabo. The Geography XI, IV. Translation and Notes by Stratanowski G. Moscow: Science, 1964, $943 \mathrm{p}$.

Waldron T. Paleopathology. Cambridge, Cambridge University Press, 2009, 279 p.

Wu H. T., Morrison W. B., Schweitzer M. E. (2006). Edematous Schmorl's nodes on thoracolumbar MR imaging: characteristic patterns and changes over time. Skeletal Radiology, 35, 212-219.

\section{Карлик в древней Армении}

\section{А.Ю. Худавердян \\ Институт археологии и этнографии НАН РА Армения, 0025, Ереван, ул. Чарениа, 15}

Описание карликов встречаются очень редко в современной научной литературе. В статье я сообщаю о возможном случае гипофизарного нанизма, который встречается в группе Бениамин из Армении (эпоха поздней античности). В статье также представлена информация об образе жизни данного индивида.

Ключевые слова: Армения, эпоха поздней античности, карлик, остеоартрит.

Научная специиальность: 07.00.00 - исторические науки. 